\title{
A FREIREAN PERSPECTIVE ON SOUTH AFRICAN TEACHER EDUCATION POLICY DEVELOPMENT
}

\author{
B. V. Botman \\ Institute for Reconciliation and Social Justice \\ University of the Free State \\ Bloemfontein, South Africa \\ e-mail: beryl.botman60@gmail.com
}

\section{ABSTRACT}

This article discusses the importance of teacher education and why Freire is an appropriate interlocutor. Freire believes that in order to become a teacher one needs to engage in the acts of studying, teaching, learning, knowing, knowledge creation and entertainment. The article describes and analyses policy on restructuring teacher education of the four democratic administrations culminating in policy. An analysis of the Policy on Minimum Requirements for Teacher Education, Qualifications and the corresponding Strategic Planning Framework includes the goals, principles, outputs and outcome, philosophy and pedagogy, as well as participatory structures. The argument is that South African teacher education policy can draw on Freirean education philosophy in order to develop explicit goals, principles, structures, philosophy and pedagogy necessary for transformation in education, in line with the responsibilities placed on teacher education through the National Development Plan.

Key words: teacher education, Paulo Freire, education philosophy, pedagogy, education policy, participatory structures in education, goals, principles

\section{INTRODUCTION}

After a long history of segregated Apartheid teacher education and training, post-Apartheid policies governing teacher education and development have gone some way in the in contributing towards transforming South African society. The particular area within the education sector that could play a pivotal role in addressing transformation is teacher education. Morrow $(2007,28)$ maintains that in order to address the challenges in education in South Africa, the 'remedy is going to have to be professional'. The pivotal role that teachers play in the system places great emphasis on the education and development of teachers. The contribution that education can make to transforming South African society leads to the choice of Paulo Freire as an interlocutor.

This article seeks to contribute to the current dialogue on higher education policy transformation. In the inquiry towards the Africanisation of education philosophy and pedagogy, many voices are included. Waghid (2005) brings together different and differing 
voices on African philosophy of education. He further explores these voices 'in defence of an African philosophy of education (that) is aimed at developing a conception of education that can contribute towards imagination, deliberation and responsibility - actions that can help towards enhancing justice in educative relations, specifically in relation to African education' (Waghid 2014, 1). The contribution of Paulo Freire and his transformatory focus on education policy could be added to the list of voices. Including Freire seems plausible in the light of similar processes in higher education transformation that are being explored. Waghid (2003, 61) describes these processes as new knowledge production, reflexive action ... deconstruction and reconstruction or constant exploring underlying issues in response to a yet unimagined future. When Van Niekerk (Waghid 2005, 208) calls for a pluralistic framework for a postmodern epistemology, the contribution of Freirean epistemology seems valuable, also because of Freire's ability towards historical, contextual and philosophical integration. It is his understanding of the South African situation, and the fact that so many used his seminal work, Pedagogy of the oppressed, as a guideline for future scenarios of education in South Africa, that the choice for him is made. What was significant in his encounters with South Africans is that he not only responded to the political, but also to the emotional needs of teachers. It is his passion against injustice in the world, including in his home country, Brazil that places the contexts within which he developed his education philosophy favourably, in order to argue for transformation in education in South Africa.

\section{PAULO FREIRE: TEACHER EDUCATION}

Throughout his career Freire gave expression to his education philosophy by making the agents within education part of his praxis. Thus, he spent time with teaching, teachers and learners. His thoughts on teacher education therefore cannot be separated from his discussions of the learning and teaching process. Stokes describes the nature of teacher education as 'a truly democratic vision of education based on experience, dialogue, reflection, and critique' (in Freire et al. 1997, 204). In order to become a teacher one needs to engage in the acts of studying, teaching, learning, knowing and entertainment (Freire 1994, 83). Freire maintains that teachers have to take their teaching practice seriously and therefore they need to study and know what they have to do.

Freire reflects on the 'banking approach' to education that limits knowledge, participation and differing views and experiences. In line with Freire's insistence on the notion that saying and doing should not contradict each other in anybody's practice, he shared his ideas on teacher education as implemented when he was Secretary of Education in São Paulo. The new quality 
of education as a project (Freire 1993, 160-163) was implemented following different stages, which included the reorientation of the curriculum based on a perspective of liberating education as a collective development through which generative themes are identified and developed. The initial stages of problematisation and systemisation implemented system-wide were followed by on-going or continuous teacher education. The first goal for the programme was the conceptualisation of the ideal school as precursor to developing a new pedagogy. The second goal was established as the need to supply elements of basic education in different areas of human knowledge. The third goal was the use of new scientific/technological developments that advance human knowledge to enhance the quality of the ideal school.

In conjunction with the goals, principles and axes, as well as some guarantees were established. The teacher education programme was based on five principles and axes (Freire 1993, 74-75). First, teachers are the subjects of their own practice, in the creation and recreation thereof. Second, the programme should provide teachers with the tools needed for creating and recreating practice based on continuous reflections on daily practices. Third, because the educational practice is always in the process of transformation, the educator should also be in constant, systematic education. Fourth, an understanding of the discovery process and origin of knowledge required by pedagogic practice should be developed. Fifth, the teacher education programme should provide the ability to reorientate the curriculum of the school.

The basic axes of the programme would be that (1) the outlook of the desired school should be the horizon of the new pedagogical proposal; (2) the provision of the basic formative components in the various areas of human knowledge are different; and (3) the acquisition of scientific advances that could enhance or promote the quality of the desired school is necessary.

Freire continues that the teacher education programme should guarantee the principle of action/reflection/action in order to advance the reconstruction of practice as transformative education. The establishment of teacher-education teams provided teachers with the opportunity for social, affective and cognitive exchange. New partnerships with universities were established on the grounds that both parties had to learn from one another. Parent training groups were also established to integrate schools with the community. Following this, the programme proved to be successful in improving the pass rate, as well as learner retention in São Paulo, which Freire attributed to ‘a true democratization of education’ (Freire 1993, 165). In societies professing democratic education systems pre-packaged teacher education is something on which Freire expressed himself very strongly. Freire (2005, 14-15) argued,

... the scientific preparation of teachers, a preparation informed by political clarity, by the capacity of teachers, by the teachers' desire to learn, and by their constant and open curiosity, represents the best political tool in defense (sic) of their interest and their right. These ingredients represent, 
in truth, real empowerment .... The development of the so-called teacher-proof materials is a continuation of experts' authoritarianism, of their total lack of faith in the possibility that teachers can know and can also create.

Teacher education programmes should prepare teachers to engage in processes of knowledge and knowledge creation with their learners and communities. Knowledge and understanding are socially constructed, and teachers and learners can be co-producers of meaning as active participants in their own learning. Teachers and learners should learn to become competent in thinking independently and critically in order to solve problems and to act as responsible citizens (Freire et al. 1997, 218). A further aspect of teacher education involves questioning. Freire (1994, 134-135) elaborated on a range of questions necessary for teaching and learning, and therefore for teacher education. He included questions regarding the nature of teaching: What is teaching? What is learning? What is the manner of the relationship between teaching and learning? There are questions pertaining to teachers and learners, such as: What is a teacher? What is the role of the teacher? What is a student or learner? What is the role of the student/learner? He also included questions on knowledge and the theory of knowledge: What is popular knowledge? With this question he was addressing cultural identity. In terms of dialogue, he posed the questions: Is it possible to be democratic and dialogical without ceasing to be a teacher, which is different from being a student? He further included questions on authoritarianism, reading and writing, codification, and the relationship between theory and practice, all of which are important questions to be dealt with in the teacher education programme and beyond. Through these questions, which are by no means meant to be exhaustive, Freire emphasised his position that pedagogy is political and gnostic.

This set of questions led to others, as illustrated by Stokes (Freire et al. 1997, 207) when he includes questions, such as these in a teacher education programme he teaches: Does the teacher create, define, and delimit discourses? Does the teacher (as author) legitimate and privilege certain meanings and interpretations over others? If so, are some voices then marginalised?

Stokes also argues that the purpose of a radical teacher education programme is to provide opportunities for all citizens to participate fully in cultural, political and economic life. The goal of education is that learners should be able to become full participants in developing their talents, potential and competencies in order to meet the social, historical and material challenges they may face. Teaching and learning are inseparable - 'there is no teaching without learning'. In the same way, thinking, listening, speaking, reading, observing and writing are all important in learning and teaching, and therefore should form the central part of teacher education and teacher praxis - 'teaching is a human act'. 


\section{POLICY ON RESTRUCTURING TEACHER EDUCATION IN SOUTH AFRICA}

Since 1994 there has been much policy development in the field of education. I will refer to the periodisation that Kruss (2009) suggests in order to put the processes of teacher education and development into perspective, but deal with policy development and implementation along the time lines of the four different democratic government administrations. In line with global trends, teacher education was moved to higher education institutions. This move meant that curriculum decisions were decentralised but nonetheless, were subject to centralised state regulation. The 'system of systems', according to Sayed (2004), also reflects the fragmented nature of the sector. The differentiated and unequal nature of the higher education sector in South Africa was also reflected in the differentiated or varying experiences of institutions and their ability to deal with restructuring and re-curriculation. Kruss $(2009,18)$ sets out to describe the restructuring programmes of the initial professional education of teachers (IPET) in the context of 'South African responses to global changes in conceptions of knowledge and the role of higher education'. At the same time, the transformation imperatives of the national Department of Education (DoE) for a new schooling system had to be developed and considered by universities when dealing with teacher education.

After the election of the democratic government, the transformation of teacher education proved to be a very complex process. The first White Paper on Education and Training (DoE 1995), also known as the Teacher Audit, set out to analyse teacher supply and demand and to use information and insights in order to address needs. All teacher education institutions and programmes were assessed in terms of staffing, governance and quality. The major findings pointed to the fragmented nature of the system. Common problems were the inadequate governance and administrative systems, poor quality of teaching and learning, as well as low output rates. Other problems were that institutions, situated in rural areas, were not costeffective and the extreme inequality of teaching and learning programmes and curricula did not extend subject knowledge beyond matric (Gordon 2009, 16-17). In addition, the powerful legacy of the old curriculum, apart from being segregated, was also firmly based in fundamental pedagogics, and was underestimated in the development of the new curriculum (Jansen and Taylor 2003, 44).

When Morrow (2007, 34-35) delivered a talk at the CORDTEK ${ }^{1}$ Conference, at the Springfield College of Education in 1994, he concluded with some lessons for teacher education. The first lesson is to undermine the scepticism about the significance of systematic learning. So the challenge for teacher education is to demonstrate to students how to care about 
systematic learning and take it seriously. The central purpose of teacher education is to initiate our students into the culture of professional teaching, with a commitment to the ideals of teaching. The second lesson is to undermine some assumptions about teaching practices, that small classes of learners work best and the emphasis on individual performance. The final lesson is to recognise that teacher education will have to be addressed in combination with teacher development, or what is traditionally called in-service training. In addition to these difficulties or lessons, conditions in schools had to be taken into account. The inadequacies include the capacities of teachers and learner-teachers, given their educational background and experience; unequal distribution of resources; and unequal conditions of schools and the availability of learning materials in classrooms. In particular, the cascade training model focused on preparing teachers to deliver a new curriculum and was inadequate in terms of the time spent being too short, being too information-driven, being removed from classroom contexts and substantive content (Jansen and Taylor 2003, 41). Before I present some issues regarding the periodisation of curriculum restructuring, I need to note that the choice of Outcomes-based education (OBE) in South Africa was unexpected. Jansen and Christie (1999, 7) describe it as a 'sudden emergence' because, until late 1996, documents pertaining to educational change made some reference to integrationist and competence discourses, but little reference to OBE. 'Then without warning, in late 1996, a key document emerged spelling out the proposal for OBE' (Jansen and Christie 1999, 7). Teachers were not called upon to participate in this decision and, in fact, it is unclear exactly who was consulted. It is also unclear whether the decision to implement OBE at the time took higher education into account. Kruss (2009) provides a trajectory of the developments within higher education in general, and teacher education in particular.

Kruss (2009) presented a periodisation of initial professional education of teachers (IPET) curriculum restructuring in the context of changing higher education and educational processes as part of a research project. She distinguished four periods. The first period, 1994 to 1999, was characterised by the response to internal restructuring dynamics driven mainly by financial imperatives and shifting conceptions of knowledge generation. The second period, 2000 to 2003, was driven by national educational transformation imperatives that included the incorporation of colleges of education into universities. The third period, 2004 to 2005, was strongly shaped by developments within higher education, where mergers between colleges and universities necessitated the formation of a new institutional landscape. In the fourth period, 2006 to 2007, teacher educators were still grappling with establishing new institutions, as well as starting to consolidate the restructuring processes and policy. I will draw from Kruss's 
periodisation but organise teacher education and development policy according to the four democratic government administrations under the specific leadership of the different Ministers of Education. These periods cannot be regarded as definitive, as different processes overlap. The reason for presenting policy development along the timelines of these administrations seeks to highlight the processes, participation and the responsibilities for development, implementation, monitoring and review. Although the focus of the discussion is educational, the processes in which these policy development take place, are administrative, with the Departments of Education and later Basic and Higher Education as accountable bodies. This choice also illustrates that education policy is political.

\section{FIRST DEMOCRATIC ADMINISTRATION: SEEKING POST-APARTHEID EDUCATION POLICIES}

The main concern of policy development was driven by the need to develop new policy frameworks for a democratic South African dispensation. Internationally, academics were engaged with the impacts of globalisation, massification and internationalisation on the curriculum. In South Africa the issues of different forms of knowledge, such as locally generated and indigenous knowledge also entered the debate. Other debates focused on skills that graduates should offer employers, academic freedom and accountability (Kruss 2009, 19).

Soon after the publication of the Teacher Audit (1995), the government started proceedings to rationalise the teaching profession by closing colleges and offering 'excess teachers' severance packages as a way of addressing the question of 'over-supply' and 'undersupply'. With the implementation of the Constitution in 1996, colleges of education became the responsibility of higher education and no longer were seen as a provincial competency as defined by the Higher Education Act of 1997. According to Sayed (2004, 253), South Africa was one of the few Anglophone African countries that did not have a separate and dedicated system of teacher education colleges. These actions run counter to an international trend where teacher education is increasingly being placed at the school level.

The state has affected a constitutional, functional shift in which colleges of education have been moved from the provincial to the national level and incorporated into universities, a process that has been under way since 2001. This move represents the first instance in postApartheid education policy when the national ministry has been able to alter the relationships with provincial ministries, albeit with provincial consent. What it signals is the state's ability to use the legislative provisions at its disposal to effect changes (Sayed 2004, 255-256). Colleges of education were effectively phased out and incorporated into the university sector 
which became the main provider of both primary and secondary teacher education. This is a direct reversal of 90 years of Apartheid teacher education policy. The decision to locate teacher education at universities has to do with 'a strong focus on 'subject/learning area content knowledge' and a research culture which universities rather than colleges are seen to provide' (Sayed 2004, 287). In making universities responsible for teacher education and not provincial departments, 'a degree of autonomy that universities enjoy, including curriculum autonomy' was secured (Sayed 2004, 287). In addition, two national initiatives had an impact on the entire education system and on curriculum restructuring in particular: a National Qualifications Framework (NQF) in 1996, and the shift to a programme-based approach to higher education funding.

The change in the curriculum for teacher education is closely linked with school curriculum changes. Curriculum 2005 or C2005 (DoE 1997) has committed education to an outcomes-based curriculum. The new curriculum poses different expectations of teachers, with the focus being on learner-centred approaches and learner competencies. The Norms and Standards for Teacher Education (NSTE) of 1997 and 2000 provide the basis for what is expected of a competent teacher. The seven roles ascribed to teachers are: learning mediators; interpreters and designers of learning programmes; leaders; administrators and managers; scholars; researchers and lifelong learners; community and pastoral players; and learning area specialists. When considering the above-mentioned roles of teachers, one is faced with the notion that, although the causes of the crisis in the education system were political, 'the remedy is going to have to be professional' (Morrow 2007, 28). Teachers are the key agents in the success of any schooling system. The commitment, quality and competence of the teachers are necessary for educational success. In order for teachers to be successful, the curriculum for teacher education and development had to be addressed. One essential way of addressing teacher education is through the restructuring of the initial professional education of teachers (IPET). Breier (2001) draws attention to the fact that the differential institutional capacity to respond to policy initiatives is strongly aligned to historical advantage. Breier (2001, 37) concludes that

There were indications that some universities had used the opportunities of the NQF to change, quite substantially, the structure of their curricular, as well as the process and pedagogy or to give attention to quality. Others had not got beyond the administrative procedures associated with qualification registration.

With teacher education becoming a national competence, the Minister of Education determines policy and standards for the professional education of teachers, and for accreditation and 
curriculum frameworks. A national process in the form of the National Norms and Standards for Educators (DoE 2000) defined new criteria for the transformation of teacher education curricula. All teacher education programmes had to be revised, subject to the approval of the Committee on Teacher Education Policy (COTEP) and, as the Heads of Education Departments Committee (HEDCOM), in line with a national core curriculum.

During this period, IPET curriculum change also responded to curriculum change in schools. The policies regarding the introduction of Outcomes-based Education and Curriculum 2005 necessitated curriculum IPET change. The South African Schools Act No. 84 (1996) which provides the regulatory framework for the system, as well as the National Norms and Standards for Public School Funding (1998), amended in 2006, 2008 and 2011, which regulates pro-poor education funding, has had an impact on teacher education policy.

\section{SECOND DEMOCRATIC ADMINISTRATION: REVIEW, REVISE AND REFINE}

This period started with the revision of the National Curriculum Statements or NSC (DoE 2002), supplemented by Criteria for Recognition and Evaluation of Qualifications for Employment in Education (DoE 2000). New teacher qualifications were introduced: a fouryear Bachelor of Education (BEd) and a one-year Postgraduate Certificate in Education (PGCE), following a three-year degree. Processes for the registration and accreditation of qualifications developed by standards-generating bodies (SGBs) and teacher education providers through South African Qualifications Authority (SAQA), the DoE and the Council on Higher Education (CHE) were set in place. Amid much contestation and heated debate, and given the stark evidence of a lack of transformation across the schooling system, a review of C2005 was undertaken to identify strategies for strengthening its implementation (DoE 2002). A review of the NQF was initiated in 2001 in response to contestation around the integration of education and training, and in particular, the integration of higher education into the NQF. A consultative document was released in 2003, with proposals around standards and qualifications, quality assurance, governance and the architecture for implementation (DoE and Department of Labour 2003). The general thrust of these reviews was to identify ways to simplify, streamline and enhance effective implementation and clarify the responsibilities and roles of the multiple regulatory agencies involved (Kruss 2009, 24).

In the same year, the challenges facing the implementation of C2005 and Outcomes-based Education in schools led to a review in the form of the Revised National Curriculum Statements Grades R-9 and the National Curriculum Statement Grades 10-12 (DoE 2002). Outcomesbased Education still forms the foundation of the curriculum. The statements serve to specify 
the minimum requirements in eight learning areas for all learners in three phases: foundation, intermediate and further education and training. Along with this new policy, the Education White Paper 6: Special Needs Education sets out the framework for a national inclusive education system (DoE 2001a).

Together with the above-mentioned revisions and new policies, the revised NSTE had an impact on teacher education and development. The revised NSTE defined seven roles for the competent teacher, and also outlined knowledge, skills and values, as well as applied competencies such as practical, foundational and reflexive. An outcomes-based approach interprets these integrated seven roles. Re-curriculation primarily consisted of repackaging existing programmes in compliance with the new qualification. The responsibility for continuing professional teacher development (CPRD) programmes was transferred to provincial departments. The provincial departments were responsible for funding and managing the programmes and skills-planning processes.

In order to review the national teacher education framework, the Ministerial Committee on Teacher Education (MCTE) was formed. According to the MCTE, the purpose of establishing the committee was not to replace the newly developed policies, but to identify barriers and develop an 'overarching Framework that will enable us to focus sharply on the decisive role of teacher education in the transformation of education' (DoE 2005, 2). In its final report to the Minister of Education in June (DoE 2005), titled, A National Framework for Teacher Education in South Africa, the MCTC made the following major recommendations: there should be three complementary subsystems in teacher education: IPET, CPTD and support systems for the aforementioned two systems; and the formulation of a career development system and qualifications for teachers. This report and the process that led to the final product can be seen as the beginning of the consolidation of teacher education policy development.

\section{THIRD DEMOCRATIC ADMINISTRATION: DRIVING QUALITY ASSURANCE}

During this period, the implementation of the Integrated Quality Management System (IQMS) policy (2004) required close attention. The policy set out to make a major contribution to improving the quality of education. The IQMS is being used for salary, as well as grade progression. In future, it will also be applied to performance rewards and incentives. Coupled with the IQMS is the planning of the National Education Evaluation Development Unit (NEEDU) to oversee the measurement and improvement of educator performance (OECD 2008, 94-95). 
In addition, selected Masters of Education (MEd), BEd, PGCE and Advanced Certificate in Education (ACE) programmes were reviewed at every public and private institution of teacher education. According to the HEQC, curriculum development was being driven by management and reporting and not by academic rationales. The National Policy Framework for Teacher Education and Development in South Africa (NPFTED) was adopted in 2007 and included policy on the following: Initial Professional Education of Teachers (IPET) referring to routes to a qualification, bursary scheme, teacher recruitment programme, quality assurance, national database and information service; Continuing Professional and Teacher Development under South African Council for Educators (SACE) management, including quality assurance and monitoring, as well as funding; and a teacher education support system in the form of a forum to assess and determine new priorities (DoE 2006).

\section{FOURTH DEMOCRATIC ADMINISTRATION: CONSOLIDATION}

This period was introduced with the division of the Ministry of Education into two separate ministries, namely the Department of Basic Education (DBE) for early learning and schools, and the Department of Higher Education and Training (DHET) for Further Education and Training (FET) and higher education institutions. In 2010, the Council on Higher Education (CHE) produced the Report on the National Review of Academic and Professional Programmes in Education. The biggest challenges facing teacher education include the poor quality of programmes; teacher education programmes not being cost-effective; and the wrong incentives driving the policies concerning the supply, utilisation and development of teachers. Referring to the content of teacher education, the CHE points to the inappropriate blend of theoretical, practical and experiential knowledge. Another weakness highlighted is the incapacity of teachers to manage learning in diverse social and educational contexts (CHE 2010, 102). Waghid $(2012,104)$ adds that the report fails to 'pinpoint the conceptual problems relating to teacher education offered by South African Universities'. The seven roles teachers are supposed to perform, set out in the Norms and Standards for Educators (DoE 2000), were not translated into teacher education programmes to prepare teachers to perform these roles. These roles are also central to the subsequent policies on teacher education.

In the fourth administration, the new, divided focus can be seen as consolidating education policy and the implementation, monitoring and evaluation thereof. The consolidation undertaken within the Department of Basic Education saw yet a further review and revision of the curriculum. While the National Curriculum Statement builds on the previous curricula and sets out to update and specify more clearly what is to be taught and learnt on a term-by-term 
basis, for Grades R to 9 and Grades 10 to 12 respectively, Curriculum and Assessment Policy Statement (CAPS) is developed as a single, comprehensive policy document that replaces Subject and Learning Area Statements, Learning Programmes and Subject Assessment Guidelines for all subjects listed in the NCS Grades R to 12.

With regard to teacher education, the consolidation started by the Ministerial Committee on Teacher Education (2003 to 2005) and the eventual National Policy Framework for Teacher Education and Development in South Africa (2006) resulted in two policy documents: The Integrated Strategic Planning Framework for Teacher Education and Development in South Africa, 2011-2025, hereafter referred to as the Plan (DHET 2011b) and The National Qualifications Framework Act 67 of 2008, Policy on the Minimum Requirements for Teacher Education Qualifications (DHET 2011a).

The Plan (DHET 2011b) aims to improve the quality of teacher education and development (TED), with the primary outcome being to improve the quality of teachers and teaching (DoE and DHET 2011, 1). The Plan puts teachers at the centre of the system. It outlines four outputs with related activities. The first two outputs are to be driven by the DBE, namely to identify and address needs for individual and systematic teacher development and to attract increasing numbers of high-achieving learners into teaching. The third output forms part of the provincial education departments, namely to enhance teacher support at the local level. The DHET will lead the fourth output, namely to establish an expanded and accessible formal teacher education system (DoE and DHET 2011, 4-18). The Plan also stipulates the following enabling implementation measures (DoE and DHET 2011, 19-21): collaboration and coherence in teacher education and development; a co-ordinated system for teacher education and development; adequate time for quality teacher education and development; and sufficient funding for quality teacher education and development.

The National Qualifications Framework Act 67 of 2008, Policy on the Minimum Requirements for Teacher Education Qualifications (DHET 2011a) replaces the Norms and Standards for Educators. The Minimum Requirements for Teacher Education Qualifications is also based on the National Review of Teacher Education Qualifications (CHE 2010), the Criteria for the Recognition and Evaluation of Qualifications for Employment in Education, based on NSE (DoE 2000b), and the National Policy Framework for Teacher Education and Development (DoE 2006).

The Minimum Requirements for Teacher Education Qualifications defines differentiated standards by selecting suitable qualification types for different purposes corresponding with NQF levels. It also defines the designator for all degrees and identifies qualifiers. Furthermore, 
it sets out credit values for learning programmes and minimum competencies for Initial Teacher Education (ITE) programmes. The Minimum Requirements for Teacher Education Qualifications also provides a basis for constructing core curricula for ITE, as well as Continuing Professional Development (CPD) programmes and deals only with school-based educators whose core responsibility is that of classroom teaching at a school (DHET 2011a, 45).

The Minimum Requirements for Teacher Education Qualifications (DHET 2011a, 8-9) identifies the following types of learning, along with the acquisition, integration and application of knowledge for teaching purposes, namely disciplinary, pedagogical, practical, fundamental, and situational learning. The types of learning are supposed to be connected to the seven roles of teachers, as well as to the basic competencies of beginner teachers, namely:

- $\quad$ a sound subject knowledge

- $\quad$ knowledge of how to teach subjects

- $\quad$ knowledge of learners and how they learn

- $\quad$ effective communication

- $\quad$ highly developed skills in literacy, numeracy and information technology

- $\quad$ knowledge about the school curriculum

- $\quad$ understanding diversity

- $\quad$ the ability to manage classrooms

- $\quad$ the capability of assessing learners reliably

- $\quad$ displaying a positive work ethic and appropriate values

- $\quad$ the ability to reflect critically with their professional community (DoE 2011a, 56).

Together with the collective roles of teachers on which teacher education and development is based, as well as the basic competencies of a beginner teacher, I will conduct an analysis of the above-mentioned types of learning.

\section{TEACHER EDUCATION POLICY AND STRATEGIC PLANNING: AN ANALYSIS}

The Policy on Minimum Requirements for Teacher Education Qualifications is a broadly consulted policy document that includes all relevant role players and sets out broad standards for teacher education qualifications. This analysis will focus on the following issues regarding the policy document: goals and principles and outputs underpinning teacher education programmes, philosophy and pedagogy and participatory structures. 


\section{GOALS, PRINCIPLES AND OUTPUTS}

As Secretary of Education in São Paulo, Freire set out the goals and principles of the teacher development programme. The goals, principles and related axes direct or place teacher education in a framework. The goals direct teacher education to the ideal or desired school in pursuit of a new pedagogy. It also delineates human knowledge and scientific advances as bases for teacher education. The principles give guidance on teachers' praxis in 'recreating' practice through reflection as part of a continuous process of transformation and teachers' engagement of and with the knowledge required by pedagogical practices. If these principles are indeed followed it becomes clear that teachers' praxis is informed by knowledge and their relationship with knowledge. Therefore, teacher education should guarantee the principle of action/reflection/action as part of the reconstructing practice of transformative education. What is clear is that these principles place the people, their development, as well as their knowledge and the development thereof, at the centre of education praxis. It is for these reasons that Freire argues philosophically for education as an expression of ontological and epistemological approaches to teaching and learning when establishing democratic practices for a society in transformation.

The Policy on the Minimum Requirements for Teacher Education Qualifications does not identify any explicit goals for teacher education as part of the background to the policy, but sets out principles and qualification types, as well as related outputs as expressed in the plan. I can identify only one principle from the policy (DHET 2011a, 7), and that relates to the notion of knowledge and learning. The first point under the heading, 'Principles underpinning the design of programmes leading to teacher education qualifications', is that knowledge should be integrated and applied, expressing different types of knowing, giving 'renewed emphasis to what is to be learned and how it is to learned'. If this is the emphasis, then what is lacking are other relevant questions, such as Why? and In whose interests are particular choices being made? The inclusion of this kind of questioning would bring teachers, learners, parents and the school community, and their knowledge, together as participants in the education process. There is no clear principle of the action/reflection/action dynamic that is based on the notion that this principle should also lead to new knowledge.

The rest of the principles are dedicated to knowledge needed for teaching purposes, presented as types of learning (DHET 2011a, 8-9). Disciplinary learning refers to the discipline of education, as well as 'specific specialised subject matter', ethics and relationships. Pedagogical learning is the knowledge of learners; learning; curriculum; methodology; and 
assessment. Practical learning refers to learning related to teaching practice. Fundamental learning means speaking a second official language and the use of information and communication technologies. Lastly, situational learning includes learning environments, as well as learning about the context and social challenges.

The identification of these 'types of learning' and the meanings attached to each one of them are not founded on any recognisable scientific knowledge system about learning. I would argue that the principles as set out in the policy document do not guide or form a foundation for developing teacher education programmes. They do not speak to the position and orientation of the teacher and the relationship or ownership of their practice. Although the principle of knowledge is made explicit through the explanations of types of learning, the development of the teacher is not placed in the same central position. Freirean education philosophy would ascribe this principle to the epistemological underpinning. What I miss at this important juncture is reference to the ontological regarding the underpinning philosophy of education.

The policy sets general requirements for 'the knowledge mix' for all teacher education qualifications. As an example, a teacher education programme for Foundation Phase would call for a knowledge mix including 'subject-focused' disciplinary, pedagogical and practical learning. This could be interpreted as meaning that since there is no reference to situational learning, it can be omitted from, for example, a programme preparing Foundation Phase teachers. Another point of concern is in regard to the purpose of the degree of Bachelor of Education, in that it calls for intellectual independence and research competence (DHET 2011a) but it is not very clear what type of learning would accommodate the development of these competencies and how these competencies would contribute to gaining credits.

The Plan sets out one outcome: to improve the quality of teacher education and development in order to improve the quality of teachers and teaching. The other organising or orientating elements identified are the outputs as stated in the strategic plan. The output specifically addressing teacher education, Output 4 (DHET 2011a, 15) deals with developing practising teachers, as well as teachers in training. The activities relate to establishing teacher knowledge in broad areas, such as numeracy, mathematics and literacy for all first languages and English First Additional Language. Other activities include enhancing teacher education institutions; establishing structures to inform enrolment for teacher education; and strengthening Foundation Phase teacher provisioning and teaching practice and experience by establishing 'teaching laboratories' and learning sites. The plan states though, that teacher knowledge and practice standards are not tied to a particular school curriculum statement, but should instead prepare teachers to deliver any curriculum (DHET 2011a, 16). I do not get a 
sense that there is a clear idea of the development of the desired school and learner, or that it forms the point of departure for teacher education. In endeavouring to give teachers a broad education, not related to any specific curriculum, there is no organising, orientating or directiongiving pedagogy or philosophy in the process of transition during this time of transformation in the country.

\section{PHILOSOPHY AND PEDAGOGY}

The teacher education policy and plan of 2011 do not refer to any particular philosophy of education that guides education in general and teacher education, in particular. The only reference to philosophy is made when outlining ‘disciplinary learning' (DHET 2011a, 8) which refers to the study of the foundations of education. There is also no suggestion of engaging philosophy of education to develop any contextual philosophy. One would expect that a society in transformation, such as South Africa, would draw on philosophies that resonate with similar orientations regarding the poor and marginalised. One would further expect that the move towards the centre of educational thought would be appropriately applied, engaged and contextualised. The debate, however, does not necessarily have to be for or against a particular philosophy, but rather to know what the education philosophy for South African education is. This article proposes the inclusion of Freirean education philosophy in the dialogue regarding transformation in education, a contributory perspective.

As for pedagogy, there is no definitive pedagogy driving South African education in general and teacher education, in particular. In fact, the idea of 'pedagogical learning' in the teacher education policy refers to the knowledge of learners, methodology and the assessment of learners' work. No reference is made to knowledge of the self as teacher. For a teacher to develop a sense of authority and become a self-directed learner, some ontological input in teacher education and development is necessary. There is nothing about questioning and the important questions that have to be posed in teacher praxis included in the understanding and application, let alone in the engagement and development of pedagogy. The issue of the important role that language plays in any educational process is also not dealt with here. In fact, the reference to language as part of one of the types of learning is included in 'fundamental learning', which refers to the ability to converse - rather than to communicate effectively - in a second official language. I would have thought that language might then be dealt with in 'situational learning', which refers to situations, contexts and environments, but it is not there either.

The process of policy development in teacher education has caused a vacuum of policy 
for an extended period - until 2011 - culminating in the Policy on the Minimum Requirements for Teacher Education Qualifications and the related Integrated Strategic Planning Framework for Teacher Education and Development in South Africa. The outcome does not call for any educational process towards forming a continuum from oppression to democracy. The Plan's organising verb in the outcome is 'improve', rather than 'change', 'transform' or 'democratise'. Thus, although there is some reference to democracy and transformation, there is no set or dedicated plan to put the process of transformation of education and teacher education into motion. The participation of teachers in their own education and development is limited. The policy does not create space for prospective teachers to participate in their own learning programme. Their participation is limited to accepting and responding to knowledge presented by experts who come with a pre-determined curriculum and course of study. The presentation of the different types of learning as proposed in the policy does not, in essence, speak to knowledge production. The knowledge of the teacher does not seem to be taken into account. Therefore, if teachers are educated in a way that does not place their knowledge, learning and teaching at the centre, they can hardly be expected to do something different in their interactions with learners. In this paradigm teachers are not expected to produce new knowledge autonomously. The participation of teachers in their own education and development is restricted to identifying development needs - notably, not initial learning - based on the interpretation of learners' assessment and diagnostic tests. Teachers may attend quality-assured courses to help in their understanding of - notably, not develop - the curriculum and learning support materials, lesson preparation and delivery. The possibility of learning - notably, not teaching - with colleagues in Professional Learning Communities (PLCs) with expert leadership might give them some opportunity of participating in their own learning. There is no clear sense that teachers and their experience, including life experience, can find a significant place in the policy or Plan.

The issues of structures and processes are important when reflecting on teacher education and development as contributing to teacher praxis as agency for an education philosophy. The structures and processes give expression to philosophical questions within education, and it is in the questioning of structures and processes that education philosophy is embodied.

\section{PARTICIPATORY STRUCTURES}

Significant work has been done to establish processes and structures within the restructuring and transformation processes in teacher education and development in post-Apartheid South Africa. The Plan sets out activities based on the policy for a period of fourteen years, by which 
time all structures should be in place, to identify and address teachers' development needs to include teachers, school leaders and subject advisors who should exist throughout the system. The challenge will be to operate these structures in line with democratic principles and the inclusion of all interest groups from education institutions. If the continuum from oppression to democracy is not stated as a clear guideline for any process and structure, the chances are that the processes and composition of structures might not reflect democratic principles or take the process of transformation of society further.

The Policy on Minimum Requirements for Teacher Education Qualifications sets out inclusive structures and processes for maximum participation, involving all role players as in the processes of developing the policy. Structures, such as Professional Learning Communities (PLCs) promise democratic participation in determining the development of teachers. The kind of activities that PLCs will engage in include the analysis of learner assessment; understanding and using related policy statements; the interpretation and use of curriculum support material developed by the Department of Basic Education (DBE); and learning from practice-related materials. However, it is not clear to what extent teachers will develop their own competence of curriculum development. If the development of the competence of curriculum development is not stated clearly in the policy, it would be difficult to lead to new knowledge as knowledge. Because all learning materials and policy interpretation seem pre-packaged for teachers to understand and use, there is no expectation of curriculum development and of the teacher as a curriculum developer. The policy does not even refer to any engagement of the knowledge that teachers bring to these arenas.

According to Policy on the Minimum Requirements for Teacher Education Qualifications, Teaching Schools (TSs) and Professional Practice Schools (PPSs) will also be established and linked to Teacher Education Institutions (TEIs) in order to focus on learning-from-practice, as well as for research. The danger of these schools lies in the strong focus on practice and not necessarily on praxis. The learners also do not seem to play any part, other than learning from teachers. If indeed there is to be 'no teaching without learning', according to Freire, then learners' participation in teaching should also be included and, indeed, how to maximise participation is an area for development. In fact, learners and parents are not included in any of the structures and processes. If structures and processes exclude learners and parents, then their inputs will not support the learning of teacher praxis.

\section{CONCLUSION}

South Africa's best prism on the future is expressed in the National Development Plan (National 
Planning Commission 2011), which requires a specific and focused role for education in general and teacher education, in particular. In the foreword, Trevor Manuel, the chairperson, presents the Vision Statement and the National Development Plan (NPC 2011, 41-48) as 'a step in the process of charting a new path for our country'. It states that South Africa has the capabilities to eradicate poverty and reduce inequality. Central to these capabilities are education and skills, as well as enabled citizens. Of the nine central challenges presented, the two most critical and interrelated are the high levels of unemployment and the poor quality of education available to the poor majority - and these 'must be the highest priorities' (NPC 2011, 3-4). In order to develop these capabilities, South Africa needs a new approach and mindset.

The Vision Statement envisions a new story for 2030 that includes every aspect of life, describing democratic life in the community, society, environment, region, continent and globe. We need to develop a new sense of ourselves, liberate ourselves, participate in our own lives, change our lives, participate in democratic processes, and live together interdependently, and sustainably on earth. An important aspect of living and working with hope lies in the development of the ability to recognise history, while working towards a worthy future.

The issues raised in the NDP pertaining to teacher education policy, resonate well with Freirean education philosophy. However, all the work done, in the way that it has been done thus far, on equity, democratisation, participation, and freeing the most vulnerable in society still does not seem to bring us close enough to quality education. We need to do something or some things differently. This is what makes education political.

\section{NOTE}

1 Council of Rectors and Deans of Teacher Education, consisting of rectors and deans at institutions that offer teacher education. They deliberate on matters pertaining to teacher education at annual conferences.

\section{REFERENCES}

Breier, M., ed. 2001. Curriculum restructuring in higher education in post-apartheid South Africa. Bellville: Education Policy Unit, University of the Western Cape.

CHE see Council for Higher Education.

Council for Higher Education. 2010. Annual report for Council for Higher Education: 2009/2010. Pretoria: Department of Education.

Department of Education. 1995. South African Schools Act, Act No 84 of 1996. Pretoria: Government Printers.

Department of Education. 1997. Curriculum 2005: Lifelong learning for the twenty-first Century. Pretoria: Department of Education.

Department of Education. 2000. Norms and standards for educators. Pretoria: Department of Education. Department of Education. 2001. Education White Paper 6: Special needs education: Building an 
inclusive education and training system. Pretoria: Department of Education.

Department of Education. 2002. Revised national curriculum statement grades 10-12. Pretoria: Department of Education.

Department of Education. 2005. Report of the ministerial committee on teacher education: A national framework for teacher education in South Africa. Pretoria: Department of Education, 16 June 2005.

Department of Education. 2006. The national policy framework for teacher education and development in South Africa. Pretoria: Department of Education.

Department of Higher Education and Training. 2011a. Policy on the minimum requirements for teacher education qualifications. Pretoria: Department of Higher Education and Training.

Department of Higher Education and Training. 2011b. Integrated strategic planning framework for teacher education and development in South Africa: 2011-2025. Pretoria: Department of Higher Education and Training.

DHET see Department of Higher Education and Training.

DoE see Department of Education.

Freire, P. 1993. Pedagogy of the city. New York: Continuum.

Freire, P. 1994. Pedagogy of hope: Reliving pedagogy of the oppressed. New York: Continuum.

Freire, P. 1997. Pedagogy of the heart. New York: Continuum.

Freire, P. 2005. Teachers as cultural workers: Letters to those who dare teach. Boulder: Westview.

Freire, P. (ed.), J. W. Frazer, D. Macedo, T. McKinnon and W. T. Stokes. 1997. Mentoring the mentor: A critical dialogue with Paulo Freire. New York: Peter Lang.

Gordon, A. 2009. Restructuring teacher education. Issues in Education Policy, No. 6. Johannesburg: Centre for Education Policy Development.

Jansen, J. and P. Christie. 1999. Changing curriculum: Studies on outcomes-based education in South Africa. Kenwyn: Juta.

Jansen, J. and N. Taylor. 2003. Educational change in South Africa 1994-2003: Case studies in largescale education reform. Country Studies, Education Reform and Management Publication Series 11(1): $1-51$.

Kruss, G., ed. 2009. Opportunities and challenges for teacher education curriculum in South Africa. Cape Town: HSRC Press.

Morrow, W. 2007. Learning to teach in South Africa. Cape Town: HSRC.

National Planning Commission. 2011. National development plan: Vision for 2030. Pretoria: National Planning Commission.

NPC see National Planning Commission.

OECD. 2008. Reviews of national policies for education: South Africa. Paris: OECD.

Sayed, Y. 2004. The case of teacher education in post-apartheid South Africa: Politics and priorities. In Changing class: Education and social change in post-apartheid South Africa, ed. L. Chisholm, 247-265. London: Zed Books.

Waghid, Y. 2003. Democratic education: Policy and praxis. Stellenbosch: Department of Education Policy Studies.

Waghid, Y. ed. 2005. African(a) philosophy of education: Reconstructions and deconstructions. Stellenbosch: Department of Education Policy Studies.

Waghid, Y. 2012. Hopeful teacher education in South Africa: Towards a politics of humanity. In Higher education for the public good: Views from the south, ed. B. Leibowitz, 101-112. Trentham: Staffordshire.

Waghid, Y. 2014. African philosophy of education reconsidered: On being human. Oxon: Routledge. 